ACTA UNIVERSITATIS WRATISLAVIENSIS

PRZEGLĄD PRAWA I ADMINISTRACJI CXXIII

WROCŁAW 2020

https://doi.org/10.19195/0137-1134.123.14

\title{
AGNIESZKA ŁUKASZCZUK
}

ORCID: 0000-0002-5350-3272

Akademia Ekonomiczno-Humanistyczna w Warszawie

\section{ZNACZENIE AKTU ŚLUBOWANIA W SŁUŻBIE CYWILNEJ W KONTEKŚCIE NABYCIA PRAW I OBOWIĄZKÓW PRZEZ URZĘDNIKA}

\begin{abstract}
Abstrakt: Skargi indywidualne składane przez osoby pokrzywdzone naruszeniem praw człowieka w zakresie ograniczenia wolności wypowiedzi i wyrażania swoich opinii zajmują ważne miejsce w systemie orzeczniczym Europejskiego Trybunału Praw Człowieka. Przyjmując subsydiarny system ochrony wolności i praw jednostek w zakresie wolności wypowiedzi i wyrażania swoich poglądów, ETPC bada zarzuty stawiane państwu-stronie Europejskiej konwencji praw człowieka i wydaje orzeczenie z uwzględnieniem standardów wynikających z instrumentów odpowiedniej i skutecznej ochrony przez nadużyciami władz państw-stron konwencji.

Rzeczpospolita przystąpiła do Europejskiej konwencji praw człowieka 26 listopada 1991 roku, ratyfikowała ją 29 stycznia 1993 roku, a następnie w drodze postanowień art. 9, 87 i 91 Konstytucji RP z 2 kwietnia 1997 roku ostatecznie ugruntowała jej miejsce w systemie powszechnie obowiązującego prawa. Konwencja stała się tym samym dokumentem zapewniającym skuteczną ochronę samodzielnego dochodzenia roszczeń przed sądami polskimi, a orzecznictwo ETPC w konkretnych sprawach znalazło odbicie nie tylko w orzeczeniach wydawanych przez sądy powszechne $\mathrm{i}$ administracyjne, lecz także przez Sąd Najwyższy i Trybunał Konstytucyjny.
\end{abstract}

Słowa kluczowe: służba cywilna, korpus służby cywilnej, urzędnicy służby cywilnej, ślubowanie, obowiązki i uprawnienia

\section{UWAGI WSTĘPNE}

Przysięga, zwana także rotą, ślubowaniem, to uroczysta wypowiedź o ustalonym uprzednio tekście, będąca publicznie złożonym oświadczeniem woli dotrzymania zobowiązania czy wywiązania się z określonych powinności. Przysięga jako instytucja prawna polega na solennym, publicznym i ustnym przyrzeczeniu określonego postępowania. Zarówno jej forma, jak i treść są urzędowo określone i dotyczą konkretnej kategorii podmiotów ${ }^{1}$.

${ }^{1}$ G. Maroń, Instytucja przysięgi (ślubowania) a poszanowanie wolności sumienia i religii, „Przegląd Prawa Konstytucyjnego” 26, 2015, nr 4, s. 52. 
Przede wszystkim przysięga składana jest przez osoby obejmujące urząd organów władzy publicznej (prezydenta, posłów, senatorów), stanowiska funkcjonariuszy publicznych (sędziów, policjantów, urzędników służby cywilnej itp.) czy też przystępujące do wykonywania zawodu zaufania publicznego (na przykład adwokatów). Przez wypowiedzenie określonych słów w określonych okolicznościach następuje objęcie urzędu lub mandatu bądź nabycie praw do wykonywania danego zawodu lub funkcji ${ }^{2}$.

Osoba składająca przysięgę zobowiązuje się do należytego sprawowania w przyszłości urzędu bądź wykonywania czynności zawodowych z poszanowaniem wskazanych w rocie przysięgi norm i wartości. Odmowa złożenia przysięgi (ślubowania) skutkuje zrzeczeniem się mandatu lub funkcji publicznej. Odrębną kategorią jest natomiast przysięga (przyrzeczenie) każdorazowo składana przez świadków w postępowaniu sądowym zobowiązująca ich do mówienia prawdy o pewnych faktach, które już zaistniały.

W artykule postawiłam następującą hipotezę: złożenie ślubowania przez osoby wykonujące zadania w imieniu i na rzecz państwa w ramach służby cywilnej ma doniosłe znaczenie ze względu na specyfikę służby, powołanej wprost do wykonywania tych zadań w ramach stosunku urzędniczego według standardów postępowania określonych w konstytucji. Zasady te (zawodowość — profesjonalizm, rzetelność, bezstronność i neutralność polityczna) są jednocześnie ustrojowymi podstawami jej działania.

Posłużyłam się w pracy metodą porównawczą, polegającą na wskazaniu podobieństw i różnic instytucji ślubowania urzędników służby cywilnej w poszczególnych ustawach o służbie cywilnej — od ustawy z 17 lutego 1922 roku o państwowej służbie cywilnej po obowiązującą ustawę z 21 października 2008 roku o służbie cywilnej.

\section{OBOWIĄZEK ZŁOŻENIA PRZYSIĘGI A NABYCIE PRAW I OBOWIĄZKÓW URZĘDNIKÓW SŁUŻBY CYWILNEJ ${ }^{3}$}

Pierwsza ustawa o państwowej służbie cywilnej z 17 lutego 1922 roku ${ }^{4}$ w tytule II $O$ urzędnikach nakładała na urzędnika mianowanego stałym obowiązek złożenia przysięgi służbowej wobec przełożonej władzy służbowej w przepisanej prawem formie. Ponadto przewidywała, że na postawie przepisów szczególnych niektórzy urzędnicy będą składać przysięgę wobec Prezydenta Rzeczypospolitej (art. 15). Z kolei wobec urzędników mianowanych prowizorycznie ${ }^{5}$ oraz prakty-

2 Ibidem.

3 J. Itrich-Drabarek, Stużba cywilna w Polsce - koncepcje i praktyka, Warszawa 2012, s. 88-95.

4 Dz.U. z 1922 r. Nr 21, poz. 164.

5 Urzędnikiem prowizorycznym był urzędnik zatrudniony na czas z góry określony, z reguły rok. Jego status w porównaniu z urzędnikiem mianowanym na stałe był ograniczony, bo nie nabywał on pełni praw związanych z pełnioną funkcją. 
kantów ustawa z 1922 roku przewidywała obowiązek złożenia przy objęciu służby przyrzeczenia w przepisanej formie służbowej, do którego stosowało się przepisy o przysiędze. Przysięga (ślubowanie) była więc istotnym elementem uzyskania przez urzędnika (mianowanego na stałe czy prowizorycznego) praw i obowiązków służbowych.

Kolejne ustawy o służbie cywilnej nie tylko nie odstąpiły od obowiązku złożenia ślubowania, lecz także nie dokonały zasadniczej modyfikacji jej treści. Ustawa o służbie cywilnej z 5 lipca 1996 roku $^{6} \mathrm{w}$ art. 33 przewidywała w ust. 1, że urzędnik służby cywilnej składa uroczyste ślubowanie następującej treści: „Ślubuję służyć Państwu Polskiemu, przestrzegać Konstytucji Rzeczypospolitej Polskiej, wykonywać obowiązki urzędnika służby cywilnej sumiennie i bezstronnie, zgodnie z najlepszą wiedzą i wolą". Złożenie ślubowania urzędnik służby cywilnej potwierdza podpisem (ust. 2). Podobnie instytucję ślubowania ustanawiała ustawa z 18 grudnia 1998 roku o służbie cywilnej ${ }^{7}$ w art. 39 ust. 1 i 3 oraz ustawa z 2006 roku o służbie cywilnej ${ }^{8} \mathrm{w}$ art. 29 , z tym że rota ślubowania została uzupełniona możliwością zakończenia jej treści słowami: „Tak mi dopomóż Bóg”.

W obowiązującej ustawie o służbie cywilnej z 21 listopada 2008 roku rota ślubowania pozostała niezmieniona. Zgodnie z art. 50 urzędnik służby cywilnej składa uroczyste ślubowanie o następującej treści: „Ślubuję służyć Państwu Polskiemu, przestrzegać Konstytucji Rzeczypospolitej Polskiej, sumiennie i bezstronnie wykonywać obowiązki urzędnika służby cywilnej zgodnie z najlepszą wiedzą i wolą" (ust. 1). Do treści ślubowania, o którym mowa w ust. 1, urzędnik służby cywilnej może dodać słowa „Tak mi dopomóż Bóg” (ust. 2). Złożenie ślubowania urzędnik służby cywilnej potwierdza podpisem (ust. 3)

Z punktu widzenia zasad etyki służby cywilnej złożenie ślubowania kształtuje odpowiednią postawę osoby zatrudnionej w służbie cywilnej. Oznacza to, że urzędnik nie może swoim postępowaniem podważać zaufania do administracji publicznej lub szkodzić dobremu imieniu instytucji, w której pracuje. Specyfiką pracy $\mathrm{w}$ administracji rządowej jest przede wszystkim służenie państwu i społeczeństwu, przestrzeganie zasad Konstytucji i innych źródeł prawa oraz poddanie się ograniczeniom, wynikającym z wykonywanych obowiązków. Szczególne obowiązki urzędnika powinny więc równoważyć uprawnienia.

Ślubowanie składane przez urzędnika służby cywilnej jest odwołaniem do zasad tej służby, mianowicie zawodowości, rzetelności, bezstronności i politycznej neutralności w wykonywaniu zadań państwa (art. 1 u.s.c.). Składając ślubowanie, urzędnik nie tylko potwierdza służenie państwu polskiemu, przestrzeganie Konstytucji, sumienne wykonywanie zadań państwa według swojej najlepszej wiedzy i woli. Akt ślubowania ma także wymiar etyczny, szczególnie wyróżniający status

${ }^{6}$ Dz.U. z 1996 r. Nr 89, poz. 402.

7 Dz.U. z 1999 r. Nr 49, poz. 483.

8 Dz.U. z 2006 r. Nr 170, poz. 1218.

9 Ustawa z dnia 21 listopada 2008 roku o służbie cywilnej, tekst jedn. Dz.U. z 2018 r. poz. $265,285$. 
urzędnika realizującego zadania państwa w ramach administracji rządowej. Ranga tych zasad jest tym bardziej doniosła, że zostały one wprost powtórzone w art. 153 Konstytucji, a zatem są filarem funkcjonowania administracji rządowej w Polsce. Ponadto złożenie ślubowania jest wyrazem respektowania przez urzędnika podstawowych, konstytucyjnych zasad ustroju państwa, mianowicie zasady dobra wspólnego (art. 1), zasady demokratycznego państwa prawnego (art. 2), zasady legalności działania organów władzy publicznej na podstawie i w granicach prawa (art. 7) czy zasady równego dostępu do służby publicznej (art. 60) ${ }^{10}$.

Ślubowanie stanowi podstawę podjęcia (dopuszczenia do wykonywania) obowiązków służbowych, zgodnie z formułą wynikającą z treści (,sumiennie i bezstronnie wykonywać obowiązki urzędnika służby cywilnej”). Dopełnieniem aktu ślubowania jest złożenie podpisu przez urzędnika służby cywilnej w chwili otrzymania przez niego aktu mianowania w formie pisemnej ${ }^{11}$. Odtąd urzędnik uzyskuje status urzędnika mianowanego, a więc może korzystać z pełni praw i obowiązków określonych w ustawie. Ich treść zarówno w poprzednich ustawach z 1998 i 2006 roku o służbie cywilnej, jak i w obowiązującej ustawie z 2008 roku pozostała niezmieniona. Konstytucja RP z 1997 roku wzmocniła znaczenie tych zasad, określając w art. 153 podstawy, na jakich powinno opierać się funkcjonowanie korpusu służby cywilnej w Polsce. Odzwierciedleniem konstytucyjnych zasad działania s.c. (zawodowej, rzetelnej, bezstronnej i politycznie neutralnej) były także przepisy dotyczące obowiązków i praw członków k.s.c. zawarte w ustawie z 1998 roku, Kodeksie etyki Służby Cywilnej z 2002 roku, a obecnie w analogicznym kształcie określa je ustawa z 2008 roku o s.c. ${ }^{12}$

Nowe zasady etyki, które zastąpiły obowiązujący dotychczas Kodeks etyki Służby Cywilnej z 2002 roku, wprowadziło zarządzenie nr 70 Prezesa Rady Ministrów w sprawie wytycznych w zakresie przestrzegania zasad służby cywilnej oraz w sprawie zasad etyki korpusu służby cywilnej ${ }^{13}$. Zarządzenie określa cztery zasady. Pierwsza odnosi się do odpowiedzialności pracowniczej i zobowiązuje pracownika (urzędnika), by na każdym etapie realizacji zadań był gotów do rozliczenia się z podejmowanych działań. Druga przewiduje obowiązek ochrony praw człowieka i obywatela przez urzędnika na podstawie zasady legalizmu i praworządności. Pracownik i urzędnik s.c. nie może się kierować uprzedzeniami względem podmiotów. Kolejna zasada oznacza zakaz uczestnictwa w strajkach, akcjach protestacyjnych zakłócających normalne funkcjonowanie urzędu. Ostatnia zasada dotyczy lojalności nie tylko wobec państwa i rządu, ale także urzędu, w którym członek korpusu

10 K. Koźmiński, [w:] Konstytucja III RP w tezach orzeczniczych Trybunału Konstytucyjnego i wybranych sadów, red. M. Zubik et al., Warszawa 2008, s. 632.

11 W. Drobny, M. Mazuryk, P. Zuzankiewicz, Ustawa o stużbie cywilnej. Komentarz, Warszawa 2010.

12 Por. W. Drobny, [w:] ibidem, s. 322-323; por. także J. Jagielski, K. Rączka, Ustawa o stużbie cywilnej. Komentarz, Warszawa 2010, s. 309-310.

13 M.P. nr 93, poz. 953. 
służby cywilnej jest zatrudniony. Zgodnie z tą zasadą urzędnik nie powinien upowszechniać poglądów, które podważałyby zaufanie obywateli do urzędu.

Określenie praw i obowiązków członków k.s.c. odnosi się do wszystkich członków k.s.c., a nie tylko do urzędników ${ }^{14}$. Katalog obowiązków wymienionych enumeratywnie w art. 76 ust. 1 ustawy zdaniem J. Jagielskiego i K. Rączki można podzielić na dwie kategorie: pierwszą — dotyczącą relacji pracodawca-zatrudniony i drugą - wykraczającą poza stosunki pracy uregulowane w prawie pracy. Kategoria stosunków pracodawca-zatrudniony obejmuje obowiązek wykonywania poleceń przełożonych, natomiast kategoria stosunków służbowych wyróżnia obowiązek przestrzegania konstytucji i przepisów prawa, rzetelnego i terminowego wykonania obowiązków, zachowania się godnie w służbie i poza nią, zachowania tajemnicy ustawowo chronionej, rozwijania wiedzy zawodowej ${ }^{15}$.

Katalog obowiązków wyliczonych w art. 76 ust. 1 ustawy z 2008 roku pokrywa się z obowiązkami sformułowanymi w ustawach o służbie cywilnej z 1998 (art. 67) i 2006 roku (art. 47) ${ }^{16}$. Dotyczą one: przestrzegania Konstytucji, ochrony interesów państwa i obywatela, racjonalnego gospodarowania środkami publicznymi, rzetelnego, bezstronnego, sprawnego i terminowego wykonywania zadań, dochowania tajemnicy ustawowo chronionej, rozwijania wiedzy zawodowej, godnego zachowania się w służbie i poza nią. Pierwszy — obowiązek przestrzegania przepisów Konstytucji — tradycyjnie już zajmuje miejsce przed innymi obowiązkami, co wyznacza ogólny kierunek działania w ramach i granicach prawa, respektowania praw i wolności jednostki w zakresie stosowania prawa, odpowiedzialność odszkodowawczą państwa, zakaz działania prawa wstecz, pierwszeństwo ustawy przed innymi aktami prawnymi. Dla członka k.s.c. obowiązująca konstytucja ma być pierwszym wyznacznikiem w podejmowaniu jego działań, podobnie jak inne obowiązki z niej wynikające, w tym obowiązek ochrony interesów państwa i praw człowieka i obywatela ${ }^{17}$, obowiązek racjonalnego gospodarowania środkami publicznymi, rzetelnego, bezstronnego, sprawnego i terminowego wykonywania powierzonych zadań ${ }^{18}$ czy obowiązek rozwijania wiedzy zawo-

${ }^{14}$ K. Stefański, Nowa ustawa o stużbie cywilnej - reforma czy kontynuacja, „Praca i Zabezpieczenie Społeczne" 2009, nr 5, s. 21; Prawo administracyjne, red. M. Wierzbowski et al., Warszawa 2008, s. 256.

15 J. Jagielski, K. Rączka, Komentarz do ustawy o stużbie cywilnej z 1998 r., Warszawa 2001, s. 224.

16 Por. A. Sarota, Zasady etyki w stużbie cywilnej, „Kwartalnik Prawa Publicznego” 2009, nr 1-2, s. 116.

17 Zdaniem autorów komentarzy do ustawy o służbie cywilnej jest to przeoczenie ustawodawcy, który kolejny raz powiela treść rozdziału 2 Konstytucji, a której obowiązek przestrzegania już określił w pkt 1 tego przepisu. Zob. P. Zuzankiewicz, [w:] W. Drobny, M. Mazuryk, P. Zuzankiewicz, op. cit., s. 327; podobnie K. Rączka, [w:] J. Jagielski, K. Rączka, Ustawa o stużbie..., s. 312.

18 Pojęcie to może być rozpatrywane zarówno w świetle art. 153 Konstytucji, formułującego cele, jakim służy powołanie s.c., jak też na podstawie art. 100 k.p., który określa sposób postępowania pracownika. Przepisy prawa pracy uzupełniają pragmatyki służbowe, dlatego odniesienie się 
dowej ${ }^{19}$. Wspólnie określone dla pracowników i urzędników obowiązki ochrony interesów państwa oraz praw człowieka i obywatela zostały uregulowane jako równoprawne sfery podlegające ochronie w taki sposób, by realizowanie zadań państwa nie odbywało się kosztem praw człowieka i obywatela, a ochrona praw człowieka nie odbywała się kosztem interesów państwa ${ }^{20}$.

Z punktu widzenia konstytucyjnej zasady neutralności politycznej s.c. najważniejsze znaczenie mają obowiązki członków k.s.c. (lub tylko urzędników czy osób zajmujących wyższe stanowiska w s.c.) w postaci zakazów określonej aktywności w życiu politycznym sformułowane w art. 77 ust. 2-7 ustawy. Są to: zakaz publicznego manifestowania poglądów politycznych (ust. 2), zakaz uczestnictwa w strajku lub akcji protestacyjnej, która zakłócałaby normalne funkcjonowanie urzędu (ust. 3), zakaz łączenia zatrudnienia w s.c. z mandatem radnego (ust. 4). Dalej idący zakaz tworzenia partii oraz uczestniczenia w nich ogranicza dodatkowo prawa urzędników w s.c. (ust. 5), a także pracowników zajmujących wyższe stanowiska w s.c. (ust. $7 \mathrm{w}$ zw. z ust. 5). Ponadto członek k.s.c. zajmujący wyższe stanowisko w s.c. nie może pełnić żadnych funkcji w związkach zawodowych (ust. 6). Są to ograniczenia bardzo restrykcyjne, o szerokim zasięgu (szerszym niekiedy pod względem podmiotowym, a także przedmiotowym, w porównaniu na przykład z ograniczeniami dotyczącymi piastowania funkcji radnego niż w ustawie z 1998 roku — art. 69 i 70), rzadko też spotykane w ustawodawstwie innych państw i rodzące wątpliwości z punktu widzenia wolności przekonań jednostki i ich wyrażania. Ustawodawca polski uznał jednak nieodzowność tego rodzaju ograniczeń wolności politycznych w naszych warunkach i pogodził je z konstytucyjnymi przesłankami ograniczenia wolności i praw (art. 31 ust. 3 Konstytucji).

Ustawa z 2008 roku, podobnie jak poprzednie ustawy o s.c., ustanawia zakaz powstania zależności służbowej między małżonkami oraz osobami, które są $\mathrm{z}$ sobą spokrewnione lub spowinowacone do drugiego stopnia, także w stosunku do osób pozostających w stosunku przysposobienia, opieki lub kurateli. Zakaz ten ma charakter bezwzględny, bo nie odnosi się on do podległości bezpośredniej, ale w ogóle do stosunku podległości służbowej ${ }^{21}$. Okoliczność podległości służbowej

do nich jest uzasadnione. Zwroty takie, jak: sumienność, rzetelność, sprawność wymagają doprecyzowania. Na potrzeby pragmatyk służbowych ich sprecyzowanie w stosunku do członków korpusu znajduje się w Kodeksie etyki SC, który pod rządami nowej ustawy o s.c. nie stracił na znaczeniu. Więcej na ten temat W. Drobny, op. cit., s. 329-330; podobnie J. Jagielski, K. Rączka, Ustawa o stużbie..., s. 314 .

19 W. Drobny, przytaczając postanowienia Kodeksu etyki SC, określa je jako obowiązek podnoszenia kompetencji potrzebnych do jak najlepszego wykonywania pracy w s.c., obowiązek znajomości aktów prawnych potrzebnych do podejmowania decyzji, uczestniczenie w szkoleniach, korzystanie z wiedzy i doświadczenia kolegów i przełożonych, z pomocy ekspertów, uzasadnienie pod kątem merytorycznym i prawnym wydawanych decyzji, idem, op. cit., s. 334.

${ }^{20}$ K. Rączka, [w:] J. Jagielski, K. Rączka, Ustawa o stużbie..., s. 311.

21 J. Jagielski, K. Rączka, Ustawa o stużbie..., s. 329; A. Dubowik, Ł. Pisarczyk, Prawo urzędnicze, Warszawa 2011, s. 154-155. 
między wymienionymi osobami mogłaby niekorzystnie wpływać na wykonywanie obowiązków członków k.s.c. i na powagę urzędu. Przepis art. 79 wskazuje wprawdzie na stosunki pokrewieństwa o charakterze rodzinnym i nie obejmuje zasięgiem grupy społecznej zaliczanej do konkubinatu, chociaż w wyroku SN z 13 kwietnia 2005 roku (IV CK 648/04) nie problem nazewnictwa, lecz skutków prawnych okazał się ważniejszy. Zdaniem SN konkubinat może wywoływać takie same skutki prawne jak rodzina, małżeństwo, pokrewieństwo, przysposobienie, opieka, kuratela ${ }^{22}$. Artykuł 79 należy moim zdaniem uznać za jedną z gwarancji konstytucyjnej zasady bezstronnego wykonywania zadań państwa. W szerszym zakresie formułuje ją przepis art. 78 w ust. 1, w którym postanawia się, że członek k.s.c. przy wykonywaniu obowiązków służbowych nie może się kierować interesem jednostkowym lub grupowym; z pewnością także rodzinnym.

Specyfika s.c. wymaga też, by członek k.s.c. nie podejmował dodatkowego zatrudnienia oprócz zatrudnienia w s.c. bez pisemnej zgody d.g.u. ani też czynności lub zajęć sprzecznych z obowiązkami wynikającymi z ustawy lub podważającymi zaufanie do s.c. (art. 80 ust. 1). Należy podkreślić, że nowa ustawa nie rodzi sprzeczności w tym zakresie z przepisem art. 65 Konstytucji, który gwarantuje każdemu wolność wyboru i wykonywania zawodu, dlatego że konstrukcja stosunku służbowego w s.c. usprawiedliwia dopuszczalność ograniczeń i obostrzeń, jakim podlegają członkowie k.s.c. ${ }^{23}$ Problem nie jest jednak dostatecznie jednoznaczny, ponieważ urzędnik, także ten zajmujący wyższe stanowisko w s.c., może się podjąć zajęć zarobkowych po uzyskaniu pisemnej zgody d.g.u. ${ }^{24}$ Definicja pojęcia „dodatkowe zajęcie zarobkowe” obejmuje wszelkie formy zarobkowania na podstawie umów cywilnoprawnych, działalności gospodarczej i stosunku pracy. Również d.g.u. obowiązuje uzyskanie pisemnej zgody na podjęcie zajęcia zarobkowego. Wniosek o wyrażenie zgody na podjęcie zajęcia dodatkowego składa on do Szefa SC. Wymaga także pisemnej opinii kierownika urzędu. Zgoda, podobnie jak w przypadku każdego członka k.s.c., jest udzielana indywidualnie. Decyzja odmowna powinna być uzasadniona ${ }^{25}$.

Wśród przepisów o obowiązkach członków k.s.c. należy zwrócić osobno uwagę na gwarancyjny charakter przeprowadzania ocen okresowych przez przełożonych wobec członków k.s.c. zatrudnionych na czas nieokreślony (art. 81-83). Przeprowadzanie ocen okresowych stanowiska pracy w s.c., nieznane ustawie

22 P. Zuzankiewicz, op. cit., s. 347; podobnie K. Rączka, [w:] J. Jagielski, K. Rączka, Ustawa o stużbie..., s. 329, z powołaniem się na ten wyrok.

${ }^{23}$ Stosunek służbowy urzędników nawiązany w drodze aktu mianowania ma charakter stosunku publicznoprawnego i charakteryzuje się wysokim stopniem podporządkowania interesów osobistych urzędnika interesom państwa. Por. A. Dubowik, Dodatkowe zatrudnienie i inne zajęcia pracowników sfery publicznej, „Praca i Zabezpieczenie Społeczne” 2005, nr 10, s. 16.

24 Ustawa z 21 sierpnia 1997 roku o ograniczeniu prowadzenia działalności gospodarczej przez osoby pełniące funkcje publiczne, Dz.U. z 2006 r. Nr 216, poz. 1584.

25 K. Rączka, [w:] J. Jagielski, K. Rączka, Ustawa o stużbie..., s. 332-334. 
z 1998 roku i po raz pierwszy wprowadzone ustawą z 2006 roku (art. 52), było podstawowym elementem rozwijającej się w tym okresie koncepcji zarządzania zasobami ludzkimi. Podobnie odniosła się do niej nowa ustawa z 2008 roku, co wymaga krótkiej charakterystyki. Ocena okresowa polega według ustawy na ocenie ,wykonywania przez członka k.s.c. obowiązków wynikających z opisu zajmowanego przez niego stanowiska pracy" (art. 81 ust. 3). Moim zdaniem w zakresie tej oceny mieści się także wykonywanie obowiązków ciążących na członku k.s.c., o których mowa w rozdziale 6 ustawy, dlatego że powinności wynikające z opisu stanowiska trudno oddzielić od całości zachowań członka k.s.c. wymaganych przez ustawę. Nie wyklucza to innej, w szczególności dyscyplinarnej odpowiedzialności za naruszenie obowiązków członka k.s.c. ${ }^{26}$

Ocena jest dokonywana co 24 miesiące (nie rzadziej niż co 12 miesięcy) przez bezpośredniego przełożonego. Ma ona służyć opisaniu i wartościowaniu wszystkich stanowisk w s.c. na podstawie ujednoliconej kategorii (grupy) stanowisk, tak by uzyskać przydatną formułę, opartą na nowych metodach zarządzania w s.c. ${ }^{27}$ Obowiązek poddania się jej jest motywem do dalszego doskonalenia w pracy zawodowej członka k.s.c. i podnoszenia swoich kwalifikacji. Albowiem gdy sprawdzian wypadnie dla ocenianego niepomyślnie, ma on możliwość poprawy w terminie 6 miesięcy od zapoznania się z oceną negatywną (art. 81 ust. 9). Dokonywanie ocen jest jednym ze środków wykonywania funkcji władczej przez władzę przełożoną ${ }^{28}$, a także sprawdzianem kwalifikacji i poziomu wykonywania obowiązków na danym stanowisku przez członka k.s.c. Najczęściej organem weryfikującym ocenę jest d.g.u., do którego kieruje się sprzeciw od oceny okresowej.

Uprawnienia członków k.s.c., zawarte w nowej ustawie z 2008 roku, należące do kategorii tak zwanych przywilejów urzędniczych, są zbieżne z uprawnieniami, jakie dotychczas przysługiwały członkom korpusu pod rządami ustaw z 1998

26 A. Łukaszczuk, Ksztaltowanie się modelu ustrojowego stużby cywilnej w Polsce, Warszawa 2014, s. 306.

27 Na podstawie oceny poszczególnych stanowisk dostosowuje się do nich zakres wymagań, a następnie kieruje się wymagania wobec członka s.c. odnośnie do wykształcenia, kwalifikacji, praktyki zawodowej itp., zob. P. Zuzankiewicz, op. cit., s. 366.

${ }^{28}$ Uchylony przepis art. 81 ust. 2 ustawy szczegółowo wymieniał katalog przełożonych dokonujących oceny. Należeli do nich: 1. szef Kancelarii Prezesa RM, właściwy minister, przewodniczący komitetu wchodzącego w skład RM, kierownik urzędu centralnego organu administracji rządowej albo wojewoda, po zasięgnięciu opinii szefa $\mathrm{SC}$ — w przypadku d.g.u.; 2. d.g.u. — w przypadku kierującego departamentem lub komórką równorzędną w urzędach, o których mowa w art. 52 pkt 2 (Kancelarii Prezesa RM, urzędzie ministra, urzędzie obsługującym przewodniczącego wchodzącego w skład RM, urzędzie centralnego organu administracji rządowej, urzędzie wojewódzkim); 3. bezpośredni przełożony — w przypadku zastępcy osób, o których mowa w pkt 2 (d.g.u.); 4. wojewoda po zasięgnięciu opinii Głównego Lekarza Weterynarii — w przypadku osób, o których mowa w art. 52 pkt 3 (wojewódzkiego lekarza weterynarii); 5. bezpośredni przełożony — w przypadku osób, o których mowa w art. 52 pkt 4 (kierującego komórką organizacyjną w Urzędzie Rejestracji Produktów Leczniczych, Wyrobów Medycznych i Produktów Biobójczych, Biurze Nasiennictwa Leśnego i ich zastępców). Warunki, sposób przeprowadzania przez nich oceny okresowej, w tym skala ocen i kryteria oceny, rodzaj formularza będą określone w drodze rozporządzenia przez prezesa RM. 
i 2006 roku o s.c. Podobnie jak poprzednie ustawy nowa ustawa dokonuje rozgraniczenia na uprawnienia przysługujące pracownikom i takie, które przysługują urzędnikom s.c., jednak rodzaj uprawnień pracowników i urzędników jest bardzo podobny. Nowa ustawa przyznała pracownikom i urzędnikom s.c. prawo do wynagrodzenia zasadniczego (w art. 85 ust. 1 - przewidzianego dla zajmowanego stanowiska wraz z dodatkami dla pracownika, w art. 85 ust. 2 - z dodatkami dla urzędnika, w art. 85 ust. 3 - z dodatkami dla urzędnika zajmującego wyższe stanowisko w służbie cywilnej), dodatek zadaniowy (art. $88 \mathrm{w} \mathrm{zw.} \mathrm{z} \mathrm{art.} 87$ ust. 1), dodatek za wieloletnią pracę (art. 90), nagrodę jubileuszową (art. 91), dodatkowe wynagrodzenie roczne (art. 92), nagrodę za szczególne osiągnięcia w pracy zawodowej (art. 93), jednorazową odprawę (art. 94), zwrot z tytułu podróży służbowych (art. 95), prawo do określonego czasu pracy (art. 97), prawo do świadczeń emerytalnych i rentowych (art. 98), prawo do innych świadczeń (art. 102), prawo do ochrony przysługującej funkcjonariuszom publicznym (art. 104). Ponadto urzędnicy s.c. mają prawo do dodatku s.c. $z$ tytułu stopnia służbowego (art. 86), prawo do otrzymania kolejnego stopnia służbowego (art. 89), prawo do ponownego zatrudnienia (art. 96). Nowa ustawa o s.c. przyznała urzędnikom także prawo do dodatkowego corocznego urlopu wypoczynkowego (art. 105).

Charakter i zasady przyznawania uprawnień pozostały niemal niezmienione w porównaniu z ustawą z 1998 i 2006 roku o s.c. Nowa ustawa, w przeciwieństwie do ustawy z 2006 roku, nie zna dodatku zależnego od specyfiki i charakteru wykonywanych zadań (art. 57 ust. 2 i 3 ustawy z 2006 roku o s.c.), dopuszcza natomiast przyznanie członkowi k.s.c. dodatku zadaniowego za wykonywanie zadań dodatkowych powierzonych przez pracodawcę (art. 88).

Podsumowując, złożenie ślubowania przez urzędnika skutkuje nabyciem praw i obowiązków określonych w ustawie o służbie cywilnej. Podstawowy podział praw i obowiązków członków korpusu służby cywilnej ogółem wynika więc ze specyfiki charakteru wykonywanych zadań przez członków korpusu służby cywilnej (urzędników i pracowników służby cywilnej). Ponadto forma nawiązania stosunku pracy w służbie cywilnej, polegająca na wyodrębnieniu dwóch kategorii podmiotów: pracowników i urzędników, ma zasadnicze znaczenie. Nawiązanie stosunku pracy $\mathrm{z}$ pracownikiem służby cywilnej w formie umowy pozwala na określenie jego obowiązków w sposób mniej rygorystyczny. Oznacza to oparcie odpowiedzialności pracownika na zasadach prawa prywatnego, dopuszczając w zamian możliwość odsunięcia od pełnienia obowiązków również w formie umownej, a więc jej ukształtowanie w wyniku porozumienia stron tej umowy ${ }^{29}$.

Natomiast nawiązanie stosunku pracy na podstawie mianowania, a więc na zasadzie jednostronnego aktu o charakterze publicznoprawnym, zapewnia urzędnikowi trwałość jego stosunku pracy i wykonywania powierzonych mu zadań, zatem i większą odpowiedzialność, karność wobec przełożonych, zakaz manifesto-

${ }^{29}$ Należy jednak mieć na względzie to, że jedną ze stron umowy było państwo (państwowy zakład pracy, organ państwowy) scentralizowane, poddane kierownictwu politycznemu jednej partii. 
wania swoich poglądów, zakaz zrzeszania się w związki zawodowe, co z kolei jest równoważone większymi uprawnieniami. Mianowanie mocniej związuje urzędnika z państwem, dając mu poczucie zaufania ze strony państwa do rzetelnego i profesjonalnego wykonywania powierzonych mu obowiązków, i także z tego względu było korzystniejszą formą nawiązania stosunku prawnego. Podkreśla też przy tym specyfikę zadań nałożonych na urzędnika. Zadania te wymagają szczególnych predyspozycji ze strony urzędnika, fachowej wiedzy, profesjonalnego i rzetelnego ich wykonania, wreszcie — zachowania neutralności politycznej.

Zatrudnienie w służbie cywilnej jest procesem trudnym i złożonym, więc przyjmuje się do służby osoby starannie wyselekcjonowane pod względem przyszłego wykonywania powierzonych im obowiązków przez państwo. Mianowanie jest podstawą zatrudnienia ściśle związaną z sektorem publicznym i takim powinno być odnośnie do realizacji zadań państwa. Powierzenie urzędnikowi stanowiska $\mathrm{w}$ formie pisma nominacyjnego umożliwia w istocie ukształtowanie się między nim a państwem stosunku prawnego opartego na szczególnej więzi prawnej o charakterze publicznoprawnym ${ }^{30}$. Zatem jedyną skuteczną formą nawiązania stosunku pracy z urzędnikiem powinno być mianowanie, ponieważ określa ono sytuację prawną urzędnika, kształtując wiele uprawnień związanych z dożywotnim pełnieniem przez niego funkcji, równoważąc wiele niedogodności związanych z pełnieniem urzędu, do których zaliczało się przede wszystkim dyspozycyjność (także poza wyznaczonymi godzinami urzędowania), zakaz manifestowania poglądów politycznych, zmiany miejsca zamieszkania bez zgody przełożonego, zakaz przynależności do związków zawodowych, wymóg odpowiedniego zachowania się także poza urzędem. Ograniczenia te, wkraczające w sferę życia prywatnego, rekompensowane miały być stabilizacją zatrudnienia, co oznaczało nieusuwalność urzędnika z powierzonego mu stanowiska ${ }^{31}$.

Wszystkie przedstawione cechy stosunku publicznoprawnego wymagają złożenia przez urzędników uroczystego ślubowania według roty określonej w art. 50 ustawy o służbie cywilnej z 2008 roku. Ustawodawca uznał ślubowanie za tak doniosłe wydarzenie, że niewywiązanie się z obowiązku złożenia ślubowania w przepisanej prawem formie czy odmowa jego złożenia przez urzędnika służby cywilnej rodzi sankcje w postaci wygaśnięcia stosunku pracy urzędnika z mocy prawa (art. 70 pkt. 1 u.s.c.). W konsekwencji dyrektor generalny urzędu wydaje decyzję w sprawie stwierdzenia wygaśnięcia stosunku pracy. Decyzja ma charakter deklaratywny, bo w jej treści zostaje potwierdzone ustanie stosunku pracy (stosunku prywatnoprawnego) oraz zakończenie służby publicznej (stosunku publicznoprawnego) $)^{32}$.

30 A. Dubowik, Trwałość stosunków pracy mianowanych urzędników państwowych a przeksztatcenia struktur państwa. Uwagi na tle reform z lat 90-tych, [w:] Stosunki pracy w stużbie cywilnej i samorzadzie terytorialnym, red. W. Sanetra, Białystok 2001, s. 126.

31 Ibidem.

32 W. Drobny, M. Mazuryk, P. Zuzankiewicz, op. cit., s. 251-252. 


\title{
ZAKOŃCZENIE
}

Problematyka ślubowania (uroczystej przysięgi) składanej przez urzędników nie była dotąd przedmiotem głębszych rozważań nauki prawa. Niemniej jednak instytucja ta ma swoją tradycję w kształtowaniu prawa służby cywilnej w Polsce od 1922 roku. Złożenie ślubowania skutkuje nabyciem praw i obowiązków przez członków k.s.c. i z tego względu nie może być ono traktowane symbolicznie i sprowadzone jedynie do czynności konwencjonalnej. Szczególną rolę ślubowanie odgrywa odnośnie do urzędników służby cywilnej ze względu na publicznoprawny charakter stosunku służbowego zawartego aktem mianowania. Od mianowanych urzędników s.c. państwo wymaga wykonywania szczególnych zadań, które wiążą się ze szczególną odpowiedzialnością. Dlatego złożenie uroczystego ślubowania wraz z przyjęciem aktu mianowania i złożenie podpisu przez urzędnika jest gwarantem rzetelnego wypełniania tych zadań w imieniu państwa.

\section{THE IMPORTANCE OF THE OATH IN THE CIVIL SERVICE IN TERMS OF ACQUISITION OF RIGHTS AND OBLIGATIONS BY AN OFFICIAL}

\author{
Summary
}

The aspect of the oath (solemn oath) taken by officials has not yet been the subject of wider consideration of legal studies. Nevertheless, this institution has a tradition in forming the law of the civil service in Poland since 1922. Taking an oath results in acquiring the rights and obligations by members of the Code of Civil Procedure. Therefore it cannot be considered as a symbol and reduced only to conventional activity.

The oath has a special role in relation to civil servants due to the public law nature of the service relationship concluded by the appointment Act. Appointed civil servants are required to perform specific tasks that involve special responsibilities. That is why, taking a solemn oath, together with the appointment act and its signature by an official, guarantees that these tasks will be performed reliably on behalf of the state.

Keywords: civil servants, civil service corps, oath, service oath

\section{BIBLIOGRAFIA}

\section{LITERATURA}

Drobny W., Mazuryk M., Zuzankiewicz P., Ustawa o stużbie cywilnej. Komentarz, Warszawa 2010. Dubowik A., Dodatkowe zatrudnienie i inne zajęcia pracowników sfery publicznej, „Praca i Zabezpieczenie Społeczne” 2005, nr 10.

Dubowik A., Trwałość stosunków pracy mianowanych urzędników państwowych a przekształcenia struktur państwa. Uwagi na tle reform z lat 90-tych, [w:] Stosunki pracy w stużbie cywilnej i samorzadzie terytorialnym, red. W. Sanetra, Białystok 2001.

Dubowik A., Pisarczyk Ł., Prawo urzędnicze, Warszawa 2011. 
Itrich-Drabarek J., Stużba cywilna w Polsce - koncepcje i praktyka, Warszawa 2012.

Jagielski J., Rączka K., Komentarz do ustawy o stużbie cywilnej z 1998 r., Warszawa 2001.

Jagielski J., Rączka K., Ustawa o stużbie cywilnej. Komentarz, Warszawa 2010.

Koźmiński K., [w:] Konstytucja III RP w tezach orzeczniczych Trybunału Konstytucyjnego $i$ wybranych sądów, red. M. Zubik et al., Warszawa 2008.

Łukaszczuk A., Kształtowanie się modelu ustrojowego stużby cywilnej w Polsce, Warszawa 2014.

Maroń G., Instytucja przysięgi (ślubowania) a poszanowanie wolności sumienia i religii, „Przegląd Prawa Konstytucyjnego" 26, 2015, nr 4.

Prawo administracyjne, red. M. Wierzbowski et al., Warszawa 2008.

Sarota A., Zasady etyki w stużbie cywilnej, „Kwartalnik Prawa Publicznego” 2009, nr 1-2.

Stefański K., Nowa ustawa o stużbie cywilnej - reforma czy kontynuacja, „Praca i Zabezpieczenie Społeczne" 2009, nr 5.

\section{ŹRÓDŁA PRAWA}

Ustawa z dnia 21 listopada 2008 roku o służbie cywilnej, tekst jedn. Dz.U. z 2018 r. poz. 265, 285. Ustawa z dnia 20 sierpnia 2006 roku o służbie cywilnej, Dz.U. z 2006 r. Nr 170, poz. 1218.

Ustawa z dnia 18 grudnia 1998 roku o służbie cywilnej, Dz.U. z 1999 r. Nr 49, poz. 483.

Ustawa z 21 sierpnia 1997 roku o ograniczeniu prowadzenia działalności gospodarczej przez osoby pełniące funkcje publiczne, tekst jedn. Dz.U. z 1997 r. Nr 106, poz. 679.

Ustawa z dnia 5 lipca 1996 roku o służbie cywilnej, Dz.U. z 1996 r. Nr 89, poz. 402.

Ustawa o państwowej służbie cywilnej z 1922 roku, Dz.U. z 1922 r. Nr 21, poz. 164.

Zarządzenie nr 70 Prezesa Rady Ministrów z dnia 6 października 2011 roku w sprawie wytycznych w zakresie przestrzegania zasad służby cywilnej oraz w sprawie zasad etyki korpusu służby cywilnej, M.P. 2011, nr 93, poz. 953. 